\title{
Economic Analysis of Rainfed Maize Production in Central Gujarat, India
}

\author{
H.C. Parmar ${ }^{1}$, Y.C. Zala ${ }^{2}$ and Vinod B. Mor ${ }^{1}$ \\ ${ }^{1}$ College of Agriculture, Anand Agricultural University, Jabugam (Gujarat), India \\ ${ }^{2}$ Principal and Dean, International Agri-business Management Institute, AAU, Anand \\ (Gujarat), India
}

*Corresponding author

\begin{tabular}{|l}
\hline K e y w o r d s \\
$\begin{array}{l}\text { cost of cultivation, } \\
\text { Marginal, Cost, } \\
\text { Maize }\end{array}$ \\
\hline Article Info \\
\hline $\begin{array}{l}\text { Accepted: } \\
\text { 20 July } 2019 \\
\text { Available Online: } \\
\text { 10 August } 2019\end{array}$ \\
\hline
\end{tabular}

\section{Introduction}

Maize or corn is one of the potential cereals grown globally, and is considered to be the third most important cereal crop after wheat and rice and gaining more popularity across the glob than any other cereal crops due to its significant utility in various forms like industrial production as a major feed source for animals and human consumption (1). Nearly 55 per cent of global maize production comes from two countries-the USA and
The present investigation was undertaken with view to study cost and returns in rain-fed maize farmers of tribal area of Central Gujarat. Multistage stratified sampling method was adopted for sample design. A sample of 240 maize farmers were selected from 12 selected villages of six selected talukas of three tribal districts. Techniques such as, percentage and ratios, mean, standard deviation and t-test were employed. Standard farm management cost and returns concepts were used to estimate various costs and returns. The results of the study revealed that, the average total cost of cultivation per hectare of maize farms was ₹ 30242. It was highest (₹ 33147.18) on large farms and the lowest (₹ 27658.29) on marginal farms. Among the different items of cash expenditure, the cost of hired labour ranks first with 11.92 per cent of total cost followed by bullock labour (8.79 per cent), chemical fertilizers (7.35 per cent), miscellaneous (5.98 per cent) and tractor charges (5.30 per cent). All the costs i.e. Cost $\mathrm{A}, \mathrm{B}, \mathrm{C}_{1}$ and $\mathrm{C}_{2}$ increased with increase in size of the farm groups. The market price of maize ranged from ₹ 1244.92 to 1528.34 per quintal from marginal farm size group to large farm size group. Therefore, it can be concluded that maize cultivation was quite remunerative even if the lowest market price was considered. 
the third most important food crop in India among the cereals and contributes nearly 9 per cent in the national food basket. In total food grain production of Gujarat, maize ranks fourth in area (4.58 lakh hectare) as well as in production (7.90 lakh $\mathrm{mt})$ and contributes nearly 11.32 per cent to the total food grain production (5). Various constraints in the present production system, an analysis at the farm level is desirable to get a clear understanding of the existence of gap between actual and potential output of agricultural crops in different regions.

\section{Materials and Methods}

Maize is grown intensively in the Central Gujarat region which accounts for 78.83 per cent of total area, contributing 80.90 per cent of total maize production in the state (5). In Central Gujarat, Panchmahal, Dahod and Chhotaudepur district are tribal districts. Maize is cultivated intensively in all these tribal districts of Central Gujarat region; as a kharif and rain-fed crop. Therefore all these districts were selected. Total of twelve villages were chosen from the six selected talukas of Dahod, Panchmahal and Chhotaudepur districts. Thus, in all 240 cultivators (107 from marginal, 86 from small, 33 from medium and 14 from large) were selected from twelve villages.

Standard farm management cost and returns concepts were used to estimate various costs and returns in the present study (according to CACP approach). Detailed estimation procedures are as follows

Cost A: It includes,

1. Value of hired human labour,

2. Value of hired bullock labour,

3. Value of owned bullock labour,

4. Value of tractor charges,

5. Value of seed/ seedlings (farm produced and/or purchased),

6. Value of manure and cakes (owned farm and/or purchased),

7. Value of fertilizers,

8. Value of insecticides and pesticides,

9. Irrigation charges,

10. Depreciation on farm buildings

11. Interest on working capital,

12. Others paid out expenses, if any.

Cost B: Cost A + Rental value of owned land + interest on value of owned fixed capital (excluding land).

Cost $\mathbf{C}_{1}$ : Cost $\mathrm{B}+$ Imputed value of family labour

Cost $\mathbf{C}_{2}$ : Cost $\mathrm{C}_{1}+10$ per cent of cost $\mathrm{C}_{1}$, as managerial charges.

The cost of expenditure incurred towards land revenue, transportation, contractual work etc., was included under the head of other paid out expenses.

\section{Imputation procedure for input costs}

The procedure adopted for deriving imputed value of these inputs is as under.

Family labour cost was imputed at the wage rates prevailing for different agricultural operations per day ( $8 \mathrm{hrs}$ ) in the selected villages.

Cost of bullock labour utilized in the cultivation of maize was reckoned as per the prevailing market rate in the villages.

Value of farm produced manure, own farm produced seeds and seedlings were computed at the prevailing rates in the concerned villages.

Cost of irrigation and tractor charges were considered at the prevailing market rates.

The kind payments were evaluated at prices prevalent in the village at the time of operations. 
Interest on working capital was charged at the rate of 12 per cent per annum.

Depreciation of owned farm buildings was calculated at the rate of 5 per cent for kachcha and 2 per cent for pucca buildings per annum.

Rental value of farmer's owned land was charged at the rate prevailing in the villages.

Management charges were calculated at the rate of 10 per cent of total cost $\left(\operatorname{Cost} \mathrm{C}_{1}\right)$.

\section{Return concept}

Gross return per hectare was estimated by adding value of main product i.e. maize per hectare and value of by-product i.e. straw per hectare. Value of main and by-product was calculated by multiplying their total quantity with its corresponding market price, while the net return/net profit per hectare was calculated by subtracting the gross return per hectare.

\section{Income measures}

These are the returns over different cost concepts. Different income measures are derived using the cost concepts. These measures used in the cost-benefit analysis of the present study are shown below;

\section{Value of gross output (Gross Income)}

Value of main product plus value of byproduct

\section{Farm business income}

Value of gross output minus Cost A

\section{Farm investment income}

Farm Business Income minus imputed value of family labour (or)

Net income plus imputed rental value of owned land plus interest on owned fixed capital invested

\section{Net Income (Net Profit)}

Value of gross output minus Cost- $\mathrm{C}_{2}$

\section{Cost per Quintal (₹ /q)}

$\underline{\text { Total cost minus value of by - product }}$ Quantity of main product (q)

\section{Results and Discussion}

The economics of crop production is determined by input prices, resource use efficiency, technology management, costs, productivity, price policy, product price and external market conditions. The inefficient use of farm resources undoubtedly affects the productivity of crops, resulting in an unfavourable costs/returns structure. To avoid such situations, the analysis of cost and returns of crop production helps in reorganizing the existing resource use pattern on individual land holdings through appropriate farm management decisions.

\section{Cost analysis of maize production}

Cost of production has paramount importance in determining the net income from different crops. Hence, the details of per hectare cost and various factor costs for the production of maize on different size of farms are studied and the results are furnished in Table 1.

The table reveals that the average total cost of cultivation per hectare of maize farms was ₹ 30242.24. On reviewing the farm size-wise total average cost of cultivation per hectare of maize, it can be seen that it was highest on large farms ( $₹$ 33147.18) and the lowest (₹ 27658.29) on marginal farms. Thus, the cost per hectare is higher on large farms as compared to medium, small and marginal 
farm (6), (7), (8) and (9). This was mainly on account of more investment on labour, tractor charges, chemical fertilizers and other miscellaneous charges by large farmers as compared to other categories of farms. Among the different items of cash expenditure, the cost of hired labour ranks first with 11.92 per cent of total cost followed by bullock labour ( 8.79 per cent), chemical fertilizers (7.35 per cent), miscellaneous (5.98 per cent) and tractor charges (5.30 per cent).

Table also indicate that among the different factor cost, family labour ranked first (21.97 percent) in total cost, because study area is tribal belt and tribal farmers do not get full time work in kharif season and this reflects on the figure of number of family member engaged in crop production (7) and (8).

\section{Estimates of different costs}

The analysis of different cost concepts such as Cost A, Cost B, Cost $\mathrm{C}_{1}$ and Cost $\mathrm{C}_{2}$ are presented in Table 2.

It can be observed from the table that Cost A formed about 59 per cent of the total cost $\left(\right.$ Cost $\left.\mathrm{C}_{2}\right)$ on maize farms. It was about 41 per cent on marginal, 47 per cent on small, 56 percent on medium and 60 percent on large farms. Cost B accounted for about 80 per cent of the total cost of maize cultivation. Cost B increased proportionately from marginal farms (61 per cent) to large farms (80 per cent).

It was also observed that Cost $\mathrm{A}$, Cost $\mathrm{B}$, Cost $\mathrm{C}_{1}$ and Cost $\mathrm{C}_{2}$ increased with increase in size of the farms (7), (8) and (9). Further the data reveals that the total cost of cultivation (Cost $\mathrm{C}_{2}$ ) per hectare of maize amounted to ₹ 27658.29, ₹ 29302.54, ₹ 31860.91 and ₹ 33147.18 on marginal, small, medium and large farms respectively, with an all farm cost of ₹ 30242.24. It can also be observed from the table that distribution of total cost (Cost
$\mathrm{C}_{2}$ ) under Cost $\mathrm{A}, \mathrm{B}$ and $\mathrm{C}_{1}$ was about 60,80 and 91 per cent respectively.

\section{Yield, price and gross income}

Maize yield per hectare, farm harvest price and value of gross output in different farm size group was estimated and presented in Table 3. The average yield of maize per hectare was the highest (23.75 quintals) on large size farm group and the lowest (21.65 quintals) on small size farm group with the 22.43 quintals on the sample as a whole. This may be due to higher level of input use by large sized farms especially tractor and fertilizers along with timely weeding operation which affect the output to a greater extent as compare to farms in the other categories (7) and (8). Considering the farmers who adopted package of practices and management of input use, there exists scope for a substantial increase in the yield if the farmers adopt the cultural practices 100 per cent and manage the inputs scientifically as recommended by the department of agriculture.

On an average, farm harvest price per quintal received by the maize growers was ₹ 1391.55. It varied from ₹ 1244.92 on marginal farms to ₹ 1528.34 on large farms. The variations in prices were mainly on account of time of sale, agencies to whom the produces were sold, distance of the market and quality of the produce. In maize production, by-product is fodder which is used for animals feed. On an average value of by-product per hectare was ₹ 6592.12.

The value of gross output per hectare was the highest ₹ 43318.83 on large farms and was lowest ₹ 33805.21 on marginal farms with ₹ 37804.59 on the sample as a whole. The value of gross output increased with an increase in the size of the farm. 
Table.1 Factor-wise Distribution of Total Cost on Maize Farms (₹ /hectare)

\begin{tabular}{|c|c|c|c|c|c|c|c|c|c|c|}
\hline \multirow[t]{3}{*}{ Item } & \multicolumn{10}{|c|}{ Farm size groups } \\
\hline & \multicolumn{2}{|c|}{ Marginal } & \multicolumn{2}{|c|}{ Small } & \multicolumn{2}{|c|}{ Medium } & \multirow{2}{*}{$\begin{array}{c}\text { Large } \\
\text { Cost }\end{array}$} & \multirow[b]{2}{*}{$\%$} & \multirow{2}{*}{$\begin{array}{c}\text { All } \\
\text { Cost }\end{array}$} & \multirow[b]{2}{*}{$\%$} \\
\hline & Cost & $\%$ & Cost & $\%$ & Cost & $\%$ & & & & \\
\hline \multicolumn{11}{|l|}{ Human labour } \\
\hline a) Family & 8387.49 & 30.33 & 7718.92 & 26.34 & 5330.95 & 16.73 & 4110.05 & 12.40 & 6644.24 & 21.97 \\
\hline b) Hired & 710.29 & 2.57 & 2454.94 & 8.38 & 5408.42 & 16.98 & 7079.42 & 21.36 & 3605.81 & 11.92 \\
\hline Bullock labour & 3172.63 & 11.47 & 3223.57 & 11.00 & 1977.20 & 6.21 & 1836.71 & 5.54 & 2657.05 & 8.79 \\
\hline Tractor charges & 1086.48 & 3.93 & 1233.35 & 4.21 & 2104.59 & 6.61 & 2280.39 & 6.88 & 1601.61 & 5.30 \\
\hline Seeds & 1172.07 & 4.24 & 1224.48 & 4.18 & 1262.17 & 3.96 & 1276.68 & 3.85 & 1231.27 & 4.07 \\
\hline Manures & 1222.97 & 4.42 & 952.61 & 3.25 & 1258.92 & 3.95 & 1368.58 & 4.13 & 1162.28 & 3.84 \\
\hline Chemical fertilizer & 2062.88 & 7.46 & 2239.35 & 7.64 & 2278.88 & 7.15 & 2322.04 & 7.01 & 2223.78 & 7.35 \\
\hline Pesticides & 322.15 & 1.16 & 295.81 & 1.01 & 441.92 & 1.39 & 466.90 & 1.41 & 368.22 & 1.22 \\
\hline Miscellaneous & 1795.21 & 6.49 & 1750.96 & 5.98 & 1837.77 & 5.77 & 1899.60 & 5.73 & 1808.33 & 5.98 \\
\hline Depreciation & 391.11 & 1.41 & 408.02 & 1.39 & 939.00 & 2.95 & 685.62 & 2.07 & 587.79 & 1.94 \\
\hline Interest on working capital & 477.40 & 1.73 & 551.32 & 1.88 & 700.36 & 2.20 & 768.68 & 2.32 & 609.85 & 2.02 \\
\hline Interest on owned fixed capital & 342.04 & 1.24 & 336.05 & 1.15 & 574.22 & 1.80 & 529.32 & 1.60 & 431.34 & 1.43 \\
\hline Rental value on owned land & 4001.08 & 14.47 & 4249.25 & 14.50 & 4850.10 & 15.22 & 5509.78 & 16.62 & 4561.32 & 15.08 \\
\hline Managerial cost & 2514.49 & 9.09 & 2663.91 & 9.09 & 2896.41 & 9.09 & 3013.41 & 9.09 & 2749.35 & 9.09 \\
\hline Total & 27658.29 & 100.0 & 29302.54 & 100.0 & 31860.91 & 100.0 & 33147.18 & 100.0 & 30242.24 & 100.0 \\
\hline
\end{tabular}


Table.2 Various Cost Concepts in the Cultivation of Maize

\begin{tabular}{|l|c|c|c|c|}
\hline \multirow{2}{*}{ Category of farms } & \multicolumn{4}{|c|}{ Different Costs (₹ per hectare) } \\
\cline { 2 - 5 } & Cost-A & Cost-B & Cost-C $_{\mathbf{1}}$ & Cost-C $_{\mathbf{2}}$ \\
\hline Marginal & 12413.19 & 16756.31 & 25143.80 & 27658.29 \\
\hline Small & $(40.55)$ & $(61.00)$ & $(90.91)$ & $(100.00)$ \\
\hline & 14334.41 & 18919.71 & 26638.63 & 29302.54 \\
\hline Medium & $(47.11)$ & $(66.35)$ & $(90.91)$ & $(100.00)$ \\
\hline & 18209.23 & 23633.55 & 28964.50 & 31860.91 \\
\hline Large & $(55.80)$ & $(75.97)$ & $(90.91)$ & $(100.00)$ \\
\hline & 19984.62 & 26023.72 & 30133.77 & 33147.18 \\
\hline All & $(60.11)$ & $(80.19)$ & $(90.91)$ & $(100.00)$ \\
\hline & 15855.99 & 20848.65 & 27492.89 & 30242.24 \\
\hline
\end{tabular}

Table.3 Yield and Value of Gross Output of Maize per Hectare

\begin{tabular}{|c|c|c|c|c|c|}
\hline \multirow{2}{*}{$\begin{array}{l}\text { Category of } \\
\text { farms }\end{array}$} & \multicolumn{2}{|c|}{ Main Production } & \multirow{2}{*}{$\begin{array}{l}\text { Value of } \\
\text { Main } \\
\text { Product } \\
\text { (Grain) } \\
\text { (₹ ) }\end{array}$} & \multirow{2}{*}{$\begin{array}{c}\text { Value of } \\
\text { by-product } \\
\text { (Fodder) } \\
\text { (₹) }\end{array}$} & \multirow{2}{*}{$\begin{array}{c}\text { Value of } \\
\text { Gross output } \\
\text { (₹ ) }\end{array}$} \\
\hline & Yield (q) & $\begin{array}{c}\text { Harvest } \\
\text { price }(₹ / q)\end{array}$ & & & \\
\hline Marginal & 22.04 & 1244.92 & 27438.04 & 6367.17 & 33805.21 \\
\hline Small & 21.65 & 1357.64 & 29392.91 & 6315.81 & 35708.72 \\
\hline Medium & 22.97 & 1464.08 & 33629.92 & 6881.89 & 40511.81 \\
\hline Large & 23.75 & 1528.34 & 36298.08 & 7020.75 & 43318.83 \\
\hline All & 22.43 & 1391.55 & 31212.47 & 6592.12 & 37804.59 \\
\hline
\end{tabular}

Table.4 Returns over Different Cost

\begin{tabular}{|l|c|c|c|c|}
\hline Category of farms & Cost A & Cost B & Cost C $_{\mathbf{1}}$ & ${\text { Cost } \mathbf{C}_{\mathbf{2}}}^{\text {A } / \text { ha) }}$ \\
\hline Marginal & 21392.02 & 17048.90 & 8661.41 & 6146.92 \\
\hline Small & 21374.31 & 16789.01 & 9070.09 & 6406.18 \\
\hline Medium & 22302.58 & 16878.26 & 11547.31 & 8650.90 \\
\hline Large & 23334.21 & 17295.11 & 13185.06 & 10171.65 \\
\hline All & 21948.60 & 16955.94 & 10311.70 & 7562.35 \\
\hline
\end{tabular}


Table.5 Farm Business Income, Farm Investment Income and Family Labour Income of Maize

\begin{tabular}{|l|c|c|c|c|}
\hline $\begin{array}{c}\text { Category of } \\
\text { farms }\end{array}$ & $\begin{array}{c}\text { Farm Business } \\
\text { Income }\end{array}$ & $\begin{array}{c}\text { Farm Investment } \\
\text { Income }\end{array}$ & $\begin{array}{c}\text { Family } \\
\text { Labour } \\
\text { Income }\end{array}$ & Net Profit \\
\hline Marginal & 21392.02 & 13004.53 & 17048.90 & 6146.92 \\
\hline Small & 21374.31 & 13655.39 & 16789.01 & 6406.18 \\
\hline Medium & 22302.58 & 16971.63 & 16878.26 & 8650.90 \\
\hline Large & 23334.21 & 19224.16 & 17295.11 & 10171.65 \\
\hline All & 21948.60 & 15304.46 & 16955.94 & 7562.35 \\
\hline
\end{tabular}

Table.6 Input-output Ratios for Maize on the basis of different Costs

\begin{tabular}{|l|c|c|c|c|}
\hline Category of farms & Cost A & Cost B & Cost $\mathbf{C}_{\mathbf{1}}$ & Cost $\mathbf{C}_{\mathbf{2}}$ \\
\hline Marginal & 2.72 & 2.02 & 1.34 & 1.22 \\
\hline Small & 2.49 & 1.89 & 1.34 & 1.22 \\
\hline Medium & 2.22 & 1.71 & 1.40 & 1.27 \\
\hline Large & 2.17 & 1.66 & 1.44 & 1.31 \\
\hline All & 2.38 & 1.81 & 1.38 & 1.25 \\
\hline
\end{tabular}

Table.7 Per Quintal Cost of Production and Price on Maize Farms

\begin{tabular}{|l|c|c|c|c|c|}
\hline \multicolumn{1}{|c|}{ Category of farms } & \multicolumn{4}{|c|}{ Costs (₹ Per quintal) } & $\begin{array}{c}\text { Average farm } \\
\text { harvest price } \\
\text { (₹ / quintal) }\end{array}$ \\
\cline { 2 - 5 } & Cost A & Cost B & Cost C & Cost C 2 & 1244.92 \\
\hline \multirow{2}{*}{ Marginal } & 274.32 & 471.38 & 851.93 & 966.02 & \\
\hline \multirow{2}{*}{ Small } & $(28.40)$ & $(48.80)$ & $(88.19)$ & $(100.00)$ & 1357.64 \\
\hline \multirow{2}{*}{ Medium } & 370.37 & 582.17 & 938.70 & 1061.74 & \\
\cline { 2 - 6 } & $(34.88)$ & $(54.83)$ & $(80.41)$ & $(100.00)$ & 1464.08 \\
\hline \multirow{2}{*}{ Large } & 493.14 & 729.28 & 961.37 & 1087.46 & \\
\cline { 2 - 6 } & $(45.35)$ & $(67.06)$ & $(88.41)$ & $(100.00)$ & 1528.34 \\
\hline \multirow{2}{*}{ All } & 545.85 & 800.13 & 973.18 & 1100.06 & 1391.55 \\
\cline { 2 - 6 } & $(49.62)$ & $(72.74)$ & $(88.47)$ & $(100.00)$ & \\
\hline
\end{tabular}

(Figures in parenthesis are indicates percentage)

\section{Returns from maize}

Net returns over different cost was estimated and given in Table 4. Table indicates that per hectare net returns over operational cost (Cost A) was the highest (₹ 23334.21) on large farms and the lowest ( $₹$ 21374.31) on small farms with an average of ₹ 21948.60 on sample farms as a whole.

Net returns from the maize farms on the basis of Cost B, Cost $\mathrm{C}_{1}$ and Cost $\mathrm{C}_{2}$ were ₹ 
16955.94, ₹ 10311.70 and ₹ 7562.35 per hectare respectively. Net returns over different costs $\left(\right.$ Cost $\left.\mathrm{C}_{1}, \mathrm{C}_{2}\right)$ increased with increase in size of farms (7) and (8). It is apparent from the table that per hectare net return on maize farms over Cost $\mathrm{C}_{2}$ ranged from ₹ 6146.92 on marginal farms to ₹ 10171.65 on large farms.

The overall farms business income, farm investment income and family labour income were ₹ 21948.60 , ₹ 15304.46 and ₹ 16955.94 per hectare respectively on the sample as a whole. The net profit per hectare (over Cost $\mathrm{C}_{2}$ ) was $₹ 7562.35$ for all farms, which increased with the size of farms. It was ₹ 6146.92 on marginal farms, ₹ 6406.18 on small farms, ₹ 8650.90 on medium farms and highest ₹ 10171.65 on large farms.

\section{Input-output ratio}

From the cost analysis the input-output ratios were worked out. These ratios for different size groups are presented in Table 6 .

The overall input-output ratio was 1.25 on the basis of Cost $\mathrm{C}_{2}$. It indicates that an investment worth ₹ 1 on all the inputs used in the cultivation of maize yielded an output worth ₹ 1.25. The input output ratio was lowest (1.22) on both small and marginal farms and highest (1.31) on large farms. This was mainly due to realization of lower prices by marginal and small farmers.

\section{Cost-price relationship}

It is the cost price relationship (cost-price ratio) generally decides the economic prosperity and the degree of commercialization on the farms. Profitability of a farm depends on its capacity to produce output at a lesser cost than the given market price.
The estimated cost of production of a quintal of maize is given in Table 4.2.6. The overall paid-out cost (Cost A) per quintal was ₹ 413.04, which was 39.17 per cent of the total cost. The Cost B came to ₹ 635.60 per quintal, which was 60.28 per cent of the total cost. The overall total cost of production $\left(\right.$ Cost $\left.\mathrm{C}_{2}\right)$ per quintal of maize was ₹ 1054.40. The market price of maize ranged from ₹ 1244.92 to 1528.34 per quintal from marginal farm size group to large farm size group. Therefore, it can be concluded that maize cultivation was quite remunerative even if the lowest market price was considered.

In conclusion, the maize cultivation in the tribal area of Central Gujarat has yielded an average net return of ₹ 7562.35 per hectare. Though the cost of cultivation was higher in large farms, the net return per hectare was also higher due to higher gross returns. Since the input-output ratio was 1.25 , maize cultivation is economical in the study area. It can also be concluded that the maize cultivation was quite remunerative even if the lowest market price was considered. The total cost of cultivation per hectare of maize farm was ₹ 30242. It was increased with an increase in the farm size group. Among the different items of cash expenditure, the cost of hired labour ranks first with 11.92 per cent of total cost followed by cost of bullock labour (8.79 per cent).

\section{References}

1. Mohan Paramkusam, Sivaramane. A socio-economic status of maize farmers of Telangana and Andhra Pradesh, India. Indian Journal of Economics and Development. 2016; 4(6), 1-6.

2. http://www.cornindia.com

3. http://www.naarm.org.in

4. www.thecropsite.com 
5. http://agri.gujarat.gov.in

6. Anonymous, $5^{\text {th }}$ AGRESCO Research Report, Department of Agricultural Economics, JAU, Junagadh. 2008; 96 $\& 128$.

7. Anonymous, $10^{\text {th }}$ AGRESCO Research Report, Department of Agricultural Economics, Anand Agricultural University, Anand. 2014; 34-39.

8. Anuradha Narala, Y.C. Zala. Technical Efficiency of Rice Farms under Irrigated Condition in Central Gujarat. Agricultural Economics Research Review., 2010; 23, 375-381.

9. A. Suresh, T.R. Keshava Reddy. Resource-Use efficiency of Paddy Cultivation in Peechi Command Area of Thrissur District of Kerela; An Economic Analysis. Agricultural Economics Research Review., 2006; 19, 159-171.

\section{How to cite this article:}

Parmar, H.C., Y.C. Zala and Vinod B. Mor. 2019. Economic Analysis of Rainfed Maize Production in Central Gujarat, India. Int.J.Curr.Microbiol.App.Sci. 8(08): 2420-2428. doi: https://doi.org/10.20546/ijcmas.2019.808.281 